\title{
Effect of Plant Growth Regulators on Flowering and Yield Parameters of Summer Crop in Acid Lime (Citrus aurantifolia Swingle) cv. Balaji
}

\author{
G. Ranganna*, K.T. Venkataramana, L. Mukundalakshmi, \\ K. Swarajyalakshmi and P. Sudhakar
}

\author{
Horticultural College and Research Institute, Anantharaju Peta, Dr. YSR Horticultural \\ University, Andhra Pradesh, India \\ *Corresponding author
}

\begin{abstract}
A B S T R A C T
The present investigation was carried out at AICRP on Citrus, Citrus Research Station, Tirupati, Andhra Pradesh during the year 2015 under Dr. YSR Horticultural University, to find out Effect of Plant growth Regulators on flowering and yield parameters of summer crop in acid lime (Citrus aurantifolia Swingle) cv. Balaji. Trees were sprayed with treatments viz Spraying GA3 @ 50 ppm during June + CCC @1000 ppm during September + KNO3 2\% during October, Spraying CCC @ 200 ppm (Chloromequat chloride) 1st in August, 2nd in September followed by light pruning in September and heavy irrigation in mid-October, Application of Paclobutrazol @ $5 \mathrm{ml}$ per meter canopy 4 times at 45 days interval starting from July to December, Spraying NAA @ 200 ppm during December, Spraying 2, 4-D @ 40 ppm during November + 20 ppm during February, Imposition of 30 days of soil moisture stress during October followed by $50 \mathrm{ppm}$ Ascorbic acid spray at release of stress, Spraying ethephon @ 200 ppm during the month of October, With holding irrigation (Bahar) for 30 days in September followed by application of recommended dose of fertilizers and irrigation in the month of November and along with control (Not spray). The data recorded from the results concluded that minimum number of days for initiation of flowering was recorded with the treatment application of spraying NAA @ 200 ppm during December, highest number of flowers per shoot was recorded with drenching of Paclobutrazol @ $5 \mathrm{ml}$ per meter for four times starting from July to December, highest percentage of flower retention recorded in the treatment spraying GA3 50 ppm during June + CCC @ 1000 ppm during September + KNO3 2\% during October, minimum number of days taken from flower to marble stage was recorded with spraying 30 days of soil moisture stress during October with $50 \mathrm{ppm}$ ascorbic acid spray at release of stress, minimum number of days taken from marble to maturity stage was recorded with control treatment and also with spraying ethephon @ 200 mg during October and maximum fruit yield per tree was recorded with Spraying GA3 @ 50 ppm during June + CCC @1000 ppm during September + KNO3@2\% during
\end{abstract}

\section{Introduction}

Acid lime (Citrus aurantifolia Swingle) is considered as most important fruit crop (Ghosh, 1990). It is considered to be native of Malayan peninsula. It belongs to the family
Rutaceae, with chromosome number $(2 \mathrm{n}=18)$. It is mainly cultivated for its multi - fold nutritional and medicinal values which made acid lime more important among the fruits. Its 
attractive appearance, penetrating aroma of peel and excellent taste gives a remarkable position to acid lime which is grown widely throughout the world (Babu, 2001). Citrus is one of the largest and most important groups of fruit crops in tropical and subtropical regions. In India, among the fruit crops citrus species covers an area of major fruit crops is $10.4 \%$ with an area of 953.40 thousand ha, with production of $1,17,42,000 \mathrm{MT}$, giving rise to Productivity of 8.7 MT per ha estimated data NHB 2015-2016. As per the data available (AP Horticulture online 201516), in Andhra Pradesh oranges and Batavia are being cultivated in 1, 21, 716 hectares with the production of $1,40,78,216 \mathrm{MT}$ and limes and lemons are grown an area of 111.09 thousand ha with production of 1717.34 thousand MT and productivity of 16.8 MT per hectares during 2015-2016 (NHB, 2016.). Acid lime fruits have great medicinal value. Being acidic in nature, acid lime fruits have great medicinal value. Acid lime is good appetizer, anti helmentic and it checks biliousness and stomach ache. Lime is used in making candy, chocolate, ice cream, pastries and 100 grams of fruit juice contains 80 percent of water, carotene, $26 \mathrm{IU}$, Vitamin A, Vitamin $\mathrm{B}_{1} 20 \mathrm{mg}$, Riboflavin $0.1 \mathrm{mg}$, Vitamin C $63 \mathrm{mg}$, Iron (Fe) $1.83 \mathrm{mg}$, Copper (Cu) $0.16 \mathrm{mg}$, Oxalo-acetic acid 0.30\%, Malic acid and alkaline salt $8.2 \%$ therefore it is very essential for human health (Rangel, 2010).

The major constraints faced by the growers of acid lime are the peak and lean production in consecutive years. Flowering in acid lime is recurrent under tropical and sub-tropical conditions unless synchronized into welldefined period of extreme stress. Since the demand for the fruit remains very high during summer it is very essential to regulate flowering that gives fruiting in the months of April and May which fetches higher returns to the grower compared to the income receive during other seasons. There is difficulty in fruit set because of incomplete pollination, hence plant growth regulators may be effectively used to increase fruit set. Hastabahar (September - October) management through the use of plant growth regulators and chemicals play an important role to get maximum fruit yields during summer (Mukunda et al., 2014). Hence there is a need to test the plant growth [Hasta-bahar (September - October)] through the use of plant growth regulators and chemicals for their role inducing flowering for the hasta bahar crop.

\section{Materials and Methods}

The present investigation were executed at AICRP on Citrus, Citrus Research Station, Tirupati, Andhra Pradesh during the year 2015 under Dr. YSR Horticultural University with nine treatments viz, Spraying $\mathrm{GA}_{3} @ 50$ ppm during June + CCC @ 1000 ppm during September $+\mathrm{KNO}_{3} 2 \%$ during October, Spraying CCC @ 200 ppm (Chloromequat chloride) $1^{\text {st }}$ in August, $2^{\text {nd }}$ in September followed by light pruning in September and heavy irrigation in mid-October, Application of Paclobutrazol @ $5 \mathrm{ml}$ per meter canopy 4 times at 45 days interval starting from July to December, Spraying NAA @ 200 ppm during December, Spraying 2, 4-D @ 40 ppm during November + 20 ppm during February, Imposition of 30 days of soil moisture stress during October followed by 50 ppm Ascorbic acid spray at release of stress, Spraying ethephon@200 ppm during the month of October, With holding irrigation (Bahar) for 30 days in September followed by application of recommended dose of fertilizers and irrigation in the month of November and along with control (Not spray). The experiment was laid out in a randomized block design with three replications. The effect of different treatments was studied on flower parameters (no of days for initiation of flowering, no of flowers per shoot, percentage 
of flower retention, number of days taken from flower to marble stage, number of days taken from marble to fruit maturity stage and fruit yield per tree) on six randomly selected trees. The mean data were subjected to statistical analysis following analysis of variance technique (Panse and Sukhathme 1985).

\section{Results and Discussion}

\section{No of days for initiation of flowering}

The data indicates that minimum number of days taken to flowering was recorded (37.07 days) in treatment with spraying NAA @ 200 ppm during December $\left(\mathrm{T}_{4}\right)$ followed by the treatment-5, i.e. spraying of 2, 4-D @ 40 ppm during November +20 ppm during February (44.25 days) and treatment-6 i.e. imposing 30 days of soil moisture stress during October with $50 \mathrm{ppm}$ ascorbic acid spray at release of stress (45.03 days). The maximum number of days taken for flowering (210.57 days) was recorded in control followed by (137.75 days) with spraying $\mathrm{GA}_{3} @ 50$ ppm during June + $\mathrm{CCC} @ 1000$ ppm during September $+\mathrm{KNO}_{3}$ $2 \%$ during October $\left(\mathrm{T}_{1}\right)$. The results are in accordance with the findings of Thirugnanavel et al., (2007) who reported that application of $\mathrm{GA}_{3} @ 50$ ppm in June + CCC @ $1000 \mathrm{ppm}$ in September $+\mathrm{KNO}_{3}$ two percent in October showed better performance in inducing flowering in September for hasta bahar crop in acid lime. The results however are in conformity with Almaguer et al., (1992) who reported that application of $\mathrm{GA}_{3}$ is found to be useful for hasta bahar flowering compared with control. Mohsen Kazemi (2014) and Nir et al., (1972) concluded the effect of exogenous gibberellins on flowering is highly influenced by concentration and time of application in relation to the stage of floral bud development. Guardiola et al., (1982) found that the application of $\mathrm{GA}_{3}$ any time from early November until bud break resulted in a significant inhibition of flowering in several Citrus species. Several other workers also reported the similar results where exogenous application of gibberellic acid inhibits the flowering (Narayanlal et al., (2013) in guava, Mudzunga et al., (2001) and Takahera (2001) in acid lime). The delay in blooming of flower bud due to $\mathrm{GA}_{3}$ treatment might be associated with its action in promoting and diverting the flow of metabolites towards vegetative buds and thus slowed down floral development. Application of NAA and 2, 4-D remarkably resulted early flower initiation compared to all other treatments. With holding water also proved effective in promoting flower initiation as carbohydrates are concentrated in the shoots which are forced to flower at release. The data have been given in table 1 .

\section{No of flowers per shoot}

The number of flowers per shoot has significantly differed between the treatments. Drenching of Paclobutrazol @ 5 ml per meter for four times starting from July to December $\left(\mathrm{T}_{3}\right)$ produced significantly highest number of flowers per shoot (16.34) followed by treatment-7 i.e. spraying ethephon @ 200 ppm during October (12.07). Whereas, the lowest number of flowers (6.88) per shoot was recorded in control treatment $\left(\mathrm{T}_{9}\right)$. Highest number of flowers per shoot was recorded with application of Paclobutrazol which could be due to the fact that Paclobutrazol inhibit the bio synthesis of $\mathrm{GA}_{3}$ and inter nodal elongation. This reduces the availability of $\mathrm{GA}_{3}$ thus, resulting in the production of more reproductive shoots as reflected in the results. Paclobutrazol might have acted as anti gibberellic compound and arrested the vegetative bud development, nucleic acid synthesis and protein metabolism. The results are in conformity with the findings of Borroto et al., (1988), Monseline and Goren (1979), Shearling and Voon (1986). Tripathi and Dhakal (2005) and Devi et al., (2011) who reported the effect of 
Paclobutrazol on off-season flower induction and increase more number of flowers per shoot in acid lime. Several other workers have also observed that Paclobutrazol when applied to soil significantly increased the number of flowers per shoot in citrus (Dhakal and Guzman, 1992) and in ornamental plants (Wilkinson and Richards, 1987). Paclobutrazol inhibits $\mathrm{GA}_{3}$ biosynthesis by blocking especially the steps in the oxidation of ent-kaurene to ent-kaurenoic acid. It mainly inhibits the function of kaurene synthetase (Sterrett, 1985, Dalziel, 1984). Therefore, flower induction in woody fruits including acid lime may be attributed to the reduced level of gibberellins below critical level for flowering. The data have been given in table 1 .

\section{Percentage of flower retention}

The highest flower retention percentage (91.12) was noticed in spraying $\mathrm{GA}_{3} @ 50$ ppm during June + CCC @ 1000 ppm during September $+\mathrm{KNO}_{3} 2 \%$ during October $\left(\mathrm{T}_{1}\right)$ followed by $(88.70 \%)$ with spraying at 200 ppm CCC first in the month of August, second in the month of in September followed by light pruning in September and heavy irrigation in mid-October. whereas, lowest flower retention $(49.95 \%)$ was recorded in control treatment. Plant growth regulators play a paramount role in citrus biology and effect several processes connected with flowering, fruit setting and fruit development.

Table.1 Effect of plant growth regulators on flower parameters of summer crop in acid lime cv. Balaji

\begin{tabular}{|c|c|c|c|}
\hline Treatments & $\begin{array}{l}\text { No of days for } \\
\text { initiation of } \\
\text { flowering }\end{array}$ & $\begin{array}{lr}\text { No } & \text { of } \\
\text { flowers per } \\
\text { shoot }\end{array}$ & $\begin{array}{l}\text { Percentage } \\
\text { of flower } \\
\text { retention } \\
\end{array}$ \\
\hline $\begin{array}{l}\mathbf{T}_{1} \text { - Spray } \mathrm{GA}_{3} @ 50 \text { ppm during June + CCC @ } 1000 \\
\text { ppm during September }+\mathrm{KNO}_{3} 2 \% \text { during October }\end{array}$ & 137.75 & 7.44 & $\begin{array}{l}91.11 \\
(72.66)\end{array}$ \\
\hline $\begin{array}{l}\mathbf{T}_{2}-\text { Sprayings } 200 \mathrm{ppm} \text { CCC (Chloromequat chloride) } \\
1^{\text {st }} \text { in august, } 2^{\text {nd }} \text { in September followed by light pruning } \\
\text { in September and heavy irrigation in mid-October }\end{array}$ & 110.00 & 11.16 & $\begin{array}{l}88.70 \\
(70.35)\end{array}$ \\
\hline $\begin{array}{l}\mathbf{T}_{3} \text {-Drenching Paclobutrazol @ } 5 \mathrm{ml} \text { per meter canopy } \\
4 \text { times starting from July to December }\end{array}$ & 100.74 & 16.34 & $\begin{array}{l}80.95 \\
(64.10)\end{array}$ \\
\hline $\mathbf{T}_{4}$. Spraying NAA @ 200 ppm during December & 37.07 & 11.37 & $\begin{array}{l}86.35 \\
(68.29)\end{array}$ \\
\hline $\begin{array}{l}\mathbf{T}_{5} \text { - Spraying 2, 4-D @ } 40 \text { ppm during November }+20 \\
\text { ppm during February }\end{array}$ & 44.25 & 8.85 & $\begin{array}{l}87.81 \\
(69.55)\end{array}$ \\
\hline $\begin{array}{l}\mathbf{T}_{6}-30 \text { days of soil moisture stress during October with } \\
50 \mathrm{ppm} \text { Ascorbic acid Spray at release of stress }\end{array}$ & 45.03 & 9.16 & $\begin{array}{l}77.98 \\
(61.99)\end{array}$ \\
\hline $\mathbf{T}_{7}$ - Spraying ethephon @ 200 ppm during October & 91.41 & 12.07 & $\begin{array}{l}67.09 \\
(54.97)\end{array}$ \\
\hline $\begin{array}{l}\mathbf{T}_{\mathbf{8}}-\text { Withholding irrigation (Bahar) for } 30 \text { days in } \\
\text { September followed by application of recommended } \\
\text { dose of fertilizers and irrigation in the month of } \\
\text { November }\end{array}$ & 57.27 & 11.62 & $\begin{array}{l}67.60 \\
(55.28)\end{array}$ \\
\hline $\mathbf{T}_{\mathbf{9}}-$ Control & 210.57 & 6.87 & $\begin{array}{l}49.95 \\
(44.95)\end{array}$ \\
\hline $\mathrm{SE}(\mathrm{m}) \pm$ & 0.481 & 0.273 & 0.757 \\
\hline CD $(5 \%)$ & 1.453 & 0.826 & 2.29 \\
\hline
\end{tabular}


Table.2 Effect of plant growth regulators on number of days taken from flower to marble stage, marble to maturity stage and yield of summer crop in acid lime cv. Balaji

\begin{tabular}{|c|c|c|c|}
\hline Treatments & $\begin{array}{l}\text { days taken from } \\
\text { flower to } \\
\text { marble stage }\end{array}$ & $\begin{array}{l}\text { days taken from } \\
\text { marble to } \\
\text { maturity stage }\end{array}$ & $\begin{array}{l}\text { Fruit } \\
\text { Yield/ } \\
\text { tree }(\mathbf{k g})\end{array}$ \\
\hline $\begin{array}{l}\mathbf{T}_{1}-\text { Spray } \mathrm{GA}_{3} @ 50 \text { ppm during June }+\mathrm{CCC} \\
@ 1000 \text { ppm during September }+\mathrm{KNO}_{3} 2 \% \\
\text { during October }\end{array}$ & 43.86 & 136.85 & 13.61 \\
\hline $\begin{array}{l}\mathbf{T}_{2} \text { - Sprayings } 200 \mathrm{ppm} \text { CCC (Chloromequat } \\
\text { chloride) } 1^{\text {st }} \text { in august, } 2^{\text {nd }} \text { in September } \\
\text { followed by light pruning in September and } \\
\text { heavy irrigation in mid-October }\end{array}$ & 45.29 & 128.20 & 10.28 \\
\hline $\begin{array}{l}\mathbf{T}_{\mathbf{3}} \text {-Drenching Paclobutrazol @ } 5 \mathrm{ml} \text { per meter } \\
\text { canopy } 4 \text { times starting from July to December }\end{array}$ & 47.07 & 129.63 & 12.08 \\
\hline $\begin{array}{llllll}\mathbf{T}_{4} \text { - Spraying NAA } & @ & 200 & \text { ppm } & \text { during } \\
\text { December }\end{array}$ & 46.67 & 131.85 & 10.11 \\
\hline $\begin{array}{l}\mathbf{T}_{5} \text { - Spraying 2, 4-D @ } 40 \text { ppm during } \\
\text { November +20 ppm during February }\end{array}$ & 46.36 & 132.70 & 9.61 \\
\hline $\begin{array}{l}\mathbf{T}_{6}-30 \text { days of soil moisture stress during } \\
\text { October with } 50 \mathrm{ppm} \text { Ascorbic acid Spray at } \\
\text { release of stress }\end{array}$ & 43.67 & 129.92 & 9.45 \\
\hline $\begin{array}{l}\mathbf{T}_{7}-\text { Spraying ethephon @ } 200 \text { ppm during } \\
\text { October }\end{array}$ & 46.38 & 126.13 & 9.30 \\
\hline $\begin{array}{l}\mathbf{T}_{\mathbf{8}}-\text { Withholding irrigation (Bahar) for } 30 \text { days } \\
\text { in September followed by application of } \\
\text { recommended dose of fertilizers and irrigation } \\
\text { in the month of November }\end{array}$ & 51.53 & 141.03 & 9.43 \\
\hline $\mathbf{T}_{9}-$ Control & 57.19 & 124.37 & 5.41 \\
\hline $\mathrm{SE}(\mathrm{m}) \pm$ & 0.456 & 0.806 & 0.067 \\
\hline CD (5\%) & 1.379 & 2.439 & 0.202 \\
\hline
\end{tabular}

The results are in accordance with the findings of Thirugnanavel et al., (2007) in acid lime who found that application of $\mathrm{GA}_{3}$ @ 50 ppm in June + CCC @ 1000 ppm in September $+\mathrm{KNO}_{3} 2 \%$ in October showed better performance in increasing number flowers per shoot, initial fruit set, fruit retention, number of fruits, and yield. Borroto et al., (1986) in Valencia orange, Debbarma and Hazarika (2016) obtained the similar results by the application of $\mathrm{GA}_{3}$ and $\mathrm{KNO}_{3}$ in citrus flowering. From the results it appeared that application of stress physically (or) spraying flowering promoting substances like CCC particularly early during October month is favoring fruit development compared to other treatments applied either early or later beyond November. The data have been given in table 1 .

\section{Number of days taken from flower to marble stage}

Time taken from flower to marble stage was lower in the treatment- 6 i.e. 30 days of soil moisture stress during October with 50 ppm ascorbic acid spray at release of stress which was closely followed by spraying $\mathrm{GA}_{3} @ 50$ ppm during June + CCC @ 1000 ppm during September $+\mathrm{KNO}_{3} 2 \%$ during October $\left(\mathrm{T}_{1}\right)$ which took 43.67 and 43.86 days respectively. However, maximum time (57.19) was 
observed in control treatment. These results reveal that growth hormones, nutrient sprays and withholding irrigation water were found effective in reducing the duration from flowering to marble stage. The data have been given in table 2 .

\section{Number of days taken from marble to fruit maturity stage}

The highest number of days (141.03) was observed in withholding irrigation for 30 days in September followed by application of recommended dose of fertilizers and irrigation in the month of November $\left(\mathrm{T}_{8}\right)$ which is found to be on par with spraying $\mathrm{GA}_{3} @ 50$ ppm during June + CCC @ 1000 ppm during September $+\mathrm{KNO}_{3} 2 \%$ during October (136.85 days). The lowest number of days (124.37) was recorded in control treatment and also with spraying ethephon @ 200 mg during October (126.16 days). From the results it appeared that in treatments where growth regulators have been applied more time is taken to attain fruit maturity stage compared to water sprayed plants (control). The reason for lower time taken for fruit maturity in ethephon treated trees could be due to the versatile role of ethylene in hastening the ripening of fruits in crops. The data have been given in table 2 .

\section{Fruit yield per tree}

Significant differences were noticed in the yield of acid lime tree due to the sprayings of different plant growth regulators. Spraying $\mathrm{GA}_{3} @ 50$ ppm during June + CCC @ 1000 ppm during September $+\mathrm{KNO}_{3} @ 2 \%$ during October $\left(T_{1}\right)$ has recorded significantly highest fruit yield per tree $(13.61 \mathrm{~kg})$ compared to all other treatments fallowed by application of Paclobutrazol @ $5 \mathrm{ml}$ per meter for four times starting from July to December $(12.08 \mathrm{~kg})$. The lowest fruit yield was recorded in control treatment $(5.41 \mathrm{~kg})$. Similar results were obtained by Mukunda et al., (2014) in acid lime. The increased fruit yield attributed to the synthesis of chlorophyll from source to sink which leads to increase carbohydrate metabolism. This might be due to more vegetative growth attained with $\mathrm{GA}_{3}$, which increased the vegetative shoot development at the initial sprays. Cycocel sprays during September enhancing flower bud initiation. $\mathrm{KNO}_{3}$ sprays at later stages could have helped to set more fruits leading highest yield per tree. The results are in agreement with the findings of Thirugnanavel et al., (2007) in acid lime, Jain et al., (2014) high yield noticed with $\mathrm{GA}_{3} 100 \mathrm{ppm}$ in Nagpur mandarin. Narayanlal et al., (2013) who reported the highest yield per plant was found in $50 \mathrm{ppm} \mathrm{GA}_{3}$ in guava. Debbarma and Hazarika (2016) also reported the $\mathrm{GA}_{3} @$ $100 \mathrm{ppm}+\mathrm{CCC} @ 1000 \mathrm{ppm}+\mathrm{KNO}_{3} 1 \%$ increases the yield in acid lime. The data have been given in table 2 .

From the investigations it can be concluded that minimum number of days for initiation of flowering was recorded with the treatment application of spraying NAA @ 200 ppm during December, highest number of flowers per shoot was recorded with drenching of Paclobutrazol@5 ml per meter for four times starting from July to December, highest percentage of flower retention recorded in the treatment spraying $\mathrm{GA}_{3} 50$ ppm during June + $\mathrm{CCC} @ 1000$ ppm during September $+\mathrm{KNO}_{3}$ $2 \%$ during October, minimum number of days taken from flower to marble stage was recorded with spraying 30 days of soil moisture stress during October with $50 \mathrm{ppm}$ ascorbic acid spray at release of stress, minimum number of days taken from marble to maturity stage was recorded with control treatment and also with spraying ethephon@ $200 \mathrm{mg}$ during October and maximum fruit yield per tree was recorded with Spraying $\mathrm{GA}_{3} @ 50$ ppm during June + CCC @ 1000 ppm during September $+\mathrm{KNO}_{3} @ 2 \%$ during October. 


\section{References}

Almaguer, V.G, Cruz, G.H. and Espinoza, J.R.E. 1992. The Effect of Growth Regulators on the Promotion of Out-of Season Harvest of Orange [Citrus sinensis (L.) Osbeck] CV 'Valencia Late' in Veracruz, Mexico. Proceedings of the International Society of Citriculture. 468-470.

Babu, R. (2001). Lime and lemons. Handbook of horticulture, ICAR. New Delhi. 212 pp.

Borroto, C.G, Escalina, M, Gonzalez, J, Blanco, M. and Nieves. N. 1988. A contribution to the flowering mechanism in Persian lime. Proceedings of International Society for Citriculture. 1: 268-271..

Dalziel, J. and Lawrenee, D.K. 1984. Bio chemical and biological effects of Kaurene oxidase inhibitors such as Paclobutrazol. In; Biochemical aspects of synthetic and naturally occurring plant growth regulators, monograph II. British Plant growth regulators group, Wantage. 43-57.

Debbarma, N. and Hazarika, B.N. 2016. Effect of plant growth regulators and chemicals on yield and quality of acid lime (Citrus aurantifolia Swingle) under foot hill condition of Arunachal Pradesh. International Journal of Agriculture, Environment and Biotechnology. 9(2): 231-236.

Devi, H.L, Sarkar, S.K, Dhanabati, L. and Majhi, D. 2011. Flushing - flowering behavior and regulation in acid lime. Journal of Crop and Weed. 7(2): 87-90.

Dhakal, D.D. and Guzman, C.C. 1992. Effect of foliar and soil application of paclobutrazol on growth and flowering of Calamondin (Citrus madurensis) trees. Inter National Journal of Agriculture and Animal Science. 13: 99102.
Ghosh, S.N, Bera, B. and Ray, S. 2012. Influence $\mathrm{f}$ plant growth regulators on fruit production of sweet orange. Journal of crop and Weed. 8(2): 83-85.

Guardiola, J.L. 1982. Flower initiation and development in Citrus. Proceedings of the International Society for Citriculture.

Jain, M.C, Choudhary, H.D, Sharma, M.K. and Bhim Singh. 2014. Yield and quality attributes of Nagpur mandarin as affected by use of different plant growth regulators. Environment and Ecology 32: 1141-45.

Mohsen Kazemi. 2014. Effect of $\mathrm{GA}_{3}$ and $\mathrm{KNO}_{3}$ spray on vegetative growth and reproductive characteristics of tomoto. International Journal of Biological and Environmental Science. 8(2): 1-9.

Mudzunga, M.J, Theron, K.I. and Rabe, E. 2001. Effects of early winter gibberellic acid and mineral oil applications on flowering of young non-bearing clementine (Citrus reticulata Blanco.) and Satsuma (Citrus unshiu Marc.) trees. S. Atr. Tydskr. Plant Grond. 18(4).

Mukunda, L.L, Venkata Ramana, K.T, Sivarama Krishna, V.N.P, Yuvaraj, K.M, Nagalakshmi, T, Sarada, G, Gourisankar, T, Gopi, V. and Gopal, K. 2014. Effect of growth regulators and chemicals on fruit yield and quality of hasta bahar flowering in acid lime (citrus aurantifolia swingle) cv. Balaji. Journal of Agriculture and Allied Sciences. 3(3): 11-13.

Narayanlal, Das, R.P. and Verma, L.R. 2013. Effect of plant growth regulators on flowering and fruit growth of guava (Psidium guajava L.) cv. Allahabad safeda. The Asian Journal of Horticulture. 8(1); 54-56.

Nir, I, Guren. And Leshem, B. 1972. Journal of American Society for Harticultural Science. 97: 776-78. 
Panse, M. and Sukhathme, K. 1985. Statistical methods for agriculture workers. Indian Council of Agriculture Research Publications. 48-67.

Rangel, C.N, Carvalho, L.M.J, Fonseca, R.B.F, Soares, A.G. and Jesus, E.O. 2010. Nutritional values of organic acid lime. Food Science and Technology. 31(4): $918-922$.

Shearling, S.J. and Voon, C.H. 1986. Paclobutrazol potential uses in citrus and mango. Memorial primer Simposium international of Citriculture. Tropical. Cuba. 1: 301-317.

Sterrett, J.P. 1985. Paclobutrazol. A promising growth inhibitor for injection into woody plants. Journal of American Society for Horticultural Science. 110(1): 4-8.

Takahara, T, Ogata, T, Koshita, Y. and
Fujisawa, H. 2001. Effect of ethychlozate, paclobutrazole and other plant growth regulators on the promotion of flowering in Citrus Bulletin of National Institute of Fruit Tree Science. 35.

Thirugnanavel, A, Amutha, R, BabyRani, W. and Indira, K. 2007. Studies on regulation of flowering in Acid lime (Citrus aurantifolia swingle). Research journal of agriculture and biological sciences. 3: 239-241.

Tripathi, K.M. and Dhakal, D.D. 2005. Effect of paclobutrazol on off-season flower induction in acid lime (Citrus aurantifolia Swingle) land races under Chitwan condition. Journal of the Institute of Agriculture and Animal Science. 26: 87-92.

\section{How to cite this article:}

Ranganna, G., K.T. Venkataramana, L. Mukundalakshmi, K. Swarajyalakshmi and Sudhakar, P. 2017. Effect of Plant Growth Regulators on Flowering and Yield Parameters of Summer Crop in Acid Lime (Citrus aurantifolia Swingle) cv. Balaji. Int.J.Curr.Microbiol.App.Sci. 6(6): 2200-2207. doi: https://doi.org/10.20546/ijcmas.2017.606.260 